\title{
THE PROPOSITION: IMAGINING RACE, FAMILY AND VIOLENCE ON THE NINETEENTH-CENTURY AUSTRALIAN FRONTIER
}

\author{
Catriona Elder \\ The University of Sydney \\ Sydney, NSW, AU
}

\begin{abstract}
This article analyses John Hillcoat's 2005 film The Proposition in relation to a spate of Australian films about violence and the (post)colonial encounter released in the early twenty-first century. Extending on Felicity Collins and Therese Davis argument that these films can be read in terms of the ways they capture or refract aspects of contemporary race relations in Australia in a post-Mabo, this article analyses how The Proposition reconstructs the trauma of the Australian frontier; how from the perspective of the twenty-first century it worries over the meaning of violence on the Australian frontier. It also explores what has become speakable (and remains unspeakable) in the public sphere about the history of the frontier encounter, especially in terms of family and race. The article argues that The Proposition and other early twenty-first century race relations films can be understood as post-reconciliation films, emerging in a period when Indigenous and non-Indigenous Australians were rethinking ideas of belonging through a prism of post-enmity and forgiveness. Drawing on the theme of violence and intimate relations in the film, this article argues that the challenges to the everyday formulation of Australian history proffered in The Proposition reveal painful and powerful differences amongst Australian citizens' understanding of who belongs and how they came to belong to the nation. I suggest that by focusing on violence in terms of intimacy, relationships, family and kin, it is possible to see this film presented an opportunity to begin to refigure ideas of belonging.
\end{abstract}

Keywords: Australian Cinema; The Western in Cinema; Frontier Violence; National Belonging; Settler Colonialism; Australian Race Relations; Gender and Family in Cinema

\section{Introduction}

John Hillcoat's 2005 film The Proposition was one of a spate of Australian films about violence and the (post)colonial encounter released in the early twentyfirst century: others included Rolf de Heer's The Tracker (2002), Louis Nowra's Black and White (2002), Phillip Noyce's internationally popular Rabbit Proof Fence (2002), Rachel Perkins' One Night the Moon (2001), and Ivan Sen's Beneath Clouds (2002) . As Felicity Collins and Therese Davis note, these types of films can be read in terms of the ways they capture or refract aspects of contemporary race relations in Australia in a post-Mabo environment (7-8). Extending on Collins and Davis's argument, this article analyses how The
Proposition reconstructs the trauma of the frontier; how from the perspective of the twenty-first century it worries over the meaning of violence on the Australian frontier. It also explores what has become speakable (and remains unspeakable) in the public sphere about the history of the frontier encounter, especially in terms of family and race.

Collins and Davis's notion of post-Mabo can be intensified and The Proposition and other early twentyfirst century race relations films can be understood as post-reconciliation films. They emerged in a period when Indigenous and non-Indigenous Australians were rethinking ideas of belonging through a prism of postenmity and forgiveness. ${ }^{1}$ As was powerfully argued in Cinema After Mabo, a suite of films inserted themselves

Catriona Elder is Associate Professor at the Department of Sociology \& Social Policy, School of Social \& Political Sciences, and the Faculty of Arts \& Social Sciences of the University of Sydney. Her email address is catriona.elder@sydney.edu.au 
into the ruptures and spaces that were opened up by the social, historical and legal debates and changes of the 1990s and beyond (Collins \& Davis). The High Court decision that recognised legal land title for Indigenous Australian land became foregrounded in racial stories. What becomes more visible in this film is violence and intimate relations. In this article, I argue that the challenges to the everyday formulation of Australian history proffered in these films, but particularly in The Proposition, reveal painful and powerful differences amongst the citizens' understanding of who belongs and how they came to belong to the nation. As many feminist and postcolonial theorists have noted, these types of relationships can be seen in the intimacy of family formation and destruction (Stoler 1995, McClintock 1995). I suggest that by focusing on violence in terms of intimacy, relationships, family and kin, it is possible to see how a film such as The Proposition presented an opportunity to begin to refigure ideas of belonging. This film sometimes operates as a site where the complexity of the relations between different groups in a postcolonial nation could be worked through, and the film often highlights possibilities that enable viewers to experience a filmic world that moves away from oppositional categories without losing sight of the ongoing inequalities that arose from colonial history (Diprose 31).

\section{Reading The Proposition}

Felicity Collins and Therese Davis suggest cinema can be understood as an "intimate public sphere of experience $[. .$.$] reprising or going back over established$ themes of national history" (Collins \& Davis 9-10). Cinema is in this sense "a public sphere which can reeducate its audience by reconstructing and reinterpreting a significant traumatic event in the history of race relations" (Collins \& Davis 11). Director John Hillcoat said that in making an historical film he wanted to "celebrate failure in our Australian history, tainted and morally compromised by violence" (cited in Krausz 20). He contrasts early Australian film that "dealt with" this morally difficult material with later "costume dramas" that he argues did not "visit" this material. This notion of revisiting the past and representing the complex and negative aspects of colonisation needs to be read alongside the argument that this return "speak[s] to the dilemmas of the present" (Collins \& Davis 11), or, as Roy Schafer puts it, "histories are present tellings" (Schafer 30). Histories and historical film tell different stories about the past, depending on the questions they set out to answer and these questions change over time (Schafer 35). Hillcoat's comments suggest that a mid-period of Australian historical films failed to confront questions of violence, perhaps reflecting a "present" whose "questions" were not concerned with issues of race. As a film made after the ten-year reconciliation period, after Mabo and Wik, and after the culture wars about Australian history, The Proposition centralises the issue of violence. Nonetheless, it is interesting to note that it ends with a question: "What are you going to do now?"

The Proposition is the imaginative outcome of work between John Hillcoat and screenwriter/musician Nick Cave. Publicity material accompanying The Proposition situates it in the field of revisionist Westerns': "Though The Proposition evokes, in iconography and scope, the great American western, Cave and Hillcoat's vision of nineteenth century Australia is wilder than anything ever imagined out west" (cited in Cenere 40). John Hillcoat said of his film:

I have always wanted to make an Australian Western. I became convinced that both through the mythic force of the rugged Australian landscape and the country's brutal history, the legendary power of the Western genre could be reinvented in a specifically Australian context. (cited in Cenere, 40)

He goes on to state:

There are the epic themes of conflict between the law and the outlaw, the oppressor and the oppressed, man and nature. The cruel reality of the Australian frontier is the story of violent conflict; white on white, white on black, black on white and black on black. Our mission was to depict this Australia as never seen before (cited in Cenere 40). 
Critics have described the film as "epic", "mythic", "reinvented" and "legendary". These are all notions that work against the idea of the documentary and suggest the generic. The result is that the film is not linked to traditional history. Instead, the address suggests titanic struggles between set groups-man and nature, "black" and "white"-rather than the very specific circumstances of a late nineteenth-century Queensland hinterland.

A significant scholarship exists on John Hillcoat's film (Collins, Dalziel, Brammer, Stadler). Much of it focuses on The Proposition as a form of Western. The Western is a sometimes popular and sometimes maligned cinematic form that has had revivals in the late 1960s and early 1990s. It is, in many ways, understood as the quintessential narrative of American nation-building. Barry Langford (2) notes there is in the genre of the Western a high degree of "reflexive selfconsciousness". He says of the genre that its "condensed, stylised and relatively settled generic universe enabled it consistently to articulate responses to currents in American social and economic history" (27). The conventions of the genre are so well-established that any reworking of them is obvious (and the political point clear). Revisionist Westerns, still set in the time and place of the classic Western, use the easily recognisable iconic themes and types of the genre-the good sheriff, the evil gunslinger, the whore with the heart of gold, the open and waiting land, the place of violence in the process of community "regeneration" (Slotkin)—and play with them to respond to contemporary political/ cultural national anxieties.

There has been increasing recognition of its transnational forms and reach of this American film form (Routt, Limbrick, Starrs). Brian McFarlane's review in Meanjin of both The Proposition and Brokeback Mountain enables a discussion of the American film and its Australian variant as two modes of the Western. McFarlane argues that much of the mise en scène of the two films-in particular the lingering widescreen shots of figures in the landscape-mark them as sophisticated examples of the genre. Bruno Starrs reads The Tracker and The Proposition as anti-Westerns, a category that emerged in the 1970s to describe westerns what were seen as self-aware and offering a critique of the colonial relations that underpinned the frontier expansion of the United States.

As with many of the articles on The Proposition Starr's argument is as much a contribution to genre studies as it is a study of the film. William Routt and Peter Limbrick's work on Australian films is also part of this oeuvre. Routt considers the early bushranger films made in Australia (circa 1910) in relation to the Western, and argues that it is the "cultural coincidences" between Australia and the United States, rather than a copycat logic that lead to the same mythical stories emerging (np). Limbrick (71-3) elaborates on this argument and introduces a settler colonial approach to explain the synergies between Australian, American and New Zealand films. Many years ago John Cawelti argued that this so-called nationalist form owed a debt to the broader genre of imperial fiction. Limbrick's work starts with this idea. Focusing on three "kangaroo westerns" made after 1945, he foregrounds the complex relationships between Australia and (the metropole) Britain and (the similarly placed settler space of) the United States. Limbrick places anxiety at the centre of this theorisation of Australian national identity and argues that the anxious logic of settler colonialismwhite masculine domination-that shaped the history of both countries has significant explanatory power in clarifying the place of the Western genre in both country's film traditions. Hillcoat, the director, also uses the Western tag to describe the film he sees as a revisionist Western. Additionally, he names in the oeuve of "anti-westerns" the Australian films The Chant of Jimmy Blacksmith (Schepisi, 1978) and Wake in Fright (Kotcheff, 1971) as influences on The Proposition. Though the writer of the screenplay, Nick Cave, says he was not thinking of the film in terms of a Western when he was writing it, this has obviously proved a productive way in which to read and think about the film.

This article acknowledges the usefulness of genre based analysis of the film. However, as significant analysis of The Proposition has already been undertaken from this perspective (see Cenere, Krausz) this article takes a different path. It recognises the film as a form of Australian Western, and then uses the ideas set out by Limbrick about this genre and settler 
colonial logics to explore issues of history, nation and belonging. Many of the key concepts that animate textual and mise en scène analyses of Westerns-for example, violence and the frontier, the family and the nation, the regeneration of white men-are concerns of this article. In particular the fact that this is a genre with a long history of worrying over national trauma is important (Heffernan 147-51).

The focus of this article is on the relationship between history and concepts of gender, civilization, race and family. To this end this article is indebted to two pieces of scholarship. Tanya Dalziell has explored the place of gender in the film, undertaking a nuanced analysis of the film's aesthetics in relation to the Stanleys-especially Mrs Stanley and her attempts at "civilisation" in the wilds of Banyon. Using the debates about historical fiction and truth that emerged around Kate Grenville's book The Secret River (2005), Felicity Collins explores the types of truth that can be produced by film. As she argues:

What is at stake, in Australia as elsewhere, is the necessity of remembering and "mourning" or "working through" a contested past-in ways that acknowledge, what Judith Butler calls the "unmourned losses" or "ungrievable lives" of the defeated, of those written out of nationbuilding histories (Collins 61).

To this end this article explores the site of the family and community in The Proposition. It explores the literal and metaphorical intimacy of the occupants of Banyon to each other, as well as their physical and moral proximity to hate and violence. In bringing this often violent inter-cultural proximity to the fore, the film exposes aspects of Australian colonial history that have often been ignored.

\section{Locating The Proposition in Australia}

This section explores the ways in which the film is located or anchored in Australian culture and history. It does so first by considering the landscape of the film and second by exploring the historical references of the film. The film is set in the 1880s on the colonial
Queensland frontier. Hillcoat noted in making The Proposition that he wanted to set it in the remote outback with "the landscape [as] one of the characters" (cited in Krausz, 18). The film was shot just outside the town of Winton (Queensland), a spot that is sometimes used in advertisements seeking to convey an archetypal vision of the Australian outback. It is also a site that is linked to Australian national history-for example as birthplace of both Qantas and "Waltzing Matilda" (Stadler 71). Peter Krausz writes that Hillcoat travelled all across Australia to help him develop the film but "especially to investigate "the power of the land and the history ingrained in it"' (18). Most reviews of the film praised the cinematography-"visually gorgeous" (Weinberg, $\mathrm{np);} \mathrm{"a} \mathrm{landscape} \mathrm{which} \mathrm{is} \mathrm{almost} \mathrm{surreally} \mathrm{captured} \mathrm{by}$ cinematographer Benoit Delhomme" (ABC, np.) - and linked the effectiveness of the film to its representation of the land: "overexposed wide-angle images of the bleak, featureless down $[\ldots]$ communicate the searing heat of the parched land and the relentless sun" (Stadler 70). At the end of his relentless search, Hillcoat chose a place that operates as anyplace in the Australian outback, but paradoxically also one that strongly signifies Australia. This moors the film in Australia; as Limbrick puts it, "in a place like terra nullius" (73)

The film can also be understood in relation to specific late twentieth-and early twenty-first-century Australian discussions around belonging, violence, land and history (Collins). Debates that were often referred to as the History Wars (McIntyre \& Clark). One place where this is particularly marked is in the film's credits. The Proposition begins with the now quite common warning for Indigenous viewers that the film contains images of deceased Indigenous peoples and that they should be aware of this in case the images cause distress. ${ }^{3}$ The opening and closing film credits are then designed around a series of historical photographs of colonial Australia. The opening credits of the film comprise a montage of historical photographs. The images begin with general photographs of Indigenous and non-Indigenous people in everyday and nonviolent scenes: posed photographs of the Native Police; inter-racial couples photographed in studios, groups of Indigenous men and non-Indigenous men posing 
for photographs, a mixed-race cricket team; a school house and students; a church choir. One photograph is identified by Stadler as featuring a local explorer of the Winton area with two Aboriginal guides (71). Felicity Collins notes these photographs are "culturally readable, iconographic scenes that are allegorically refigured" (67). The images are not deployed to create a sense that the fictional narrative that follows is part of an "alleged factual past" (Keller 51) but "to correspond to scenes of violence in the film" (Collins 67).

The soundtrack accompanying the set of historical images that begin the film features a child singing a traditional hymn:

There is a happy place far, far way.

Where saints in glory stand bright, bright as day.

O how they sweetly sing, worthy is our saviour king.

Loud let his praises ring. Praise, praise for aye.

The first photographs and the song produce in the viewer a sense that the Australian colonial past was one of co-operation, peace and innocence. The photographs show both Indigenous and non-Indigenous people, in orderly situations, with everyone carefully and neatly dressed in Western clothing. The use of photographs alludes to a well-accepted link between the archive and historical veracity. They suggest the coming nation and they also locate the events as within the modern (mechanical) period.

The montage of photographs and the clear and innocent voice of the child singing continue after the title of the film-The Proposition-appears on screen. However, at this point the historical images are substituted with sepia toned contemporary photographs that begin to tell the back story/narrative of the film: the death by murder of the Hopkins family and the hunt for their killers, a gang of Irish outlaws. Already the film calls into question the idea of the document and history. As with the earlier photographs these images, though they feature death, are in general peaceful-the dead lie neatly placed together on a bed, a coffin is surrounded by flowers, three grave sites are marked out with white stones. So, the sense of
Australia or the frontier space that was first produced, a place where Indigenous and non-Indigenous peoples come together, in cooperation, is replaced with a more complex and contradictory vision of death and possibly violence. The opening credit sequence with its subtle and calculated shift from "history" to "fiction" suggests the film will engage with the present-questions raised by the History Wars and Reconciliation. As will be discussed in detail later, the latter images that presage the film represent non-Indigenous violence enacted on other non-Indigenous peoples. In a subtle shift the plot pivots around Anglo-Irish violence-the Irish gang and the English constabulary-rather than Indigenous/ non-Indigenous violence (Dalziell 127).

In the closing credits historic photographs are used again. In this sequence the photographs are less prominent (they are smaller and appear alongside the rolling credits) and do not begin until quite late in the credits. It is worth noting that the chance that these images will be seen by most viewers of the film is low. As MacFarlane (68) wrote, he only viewed this part of the credits on his second viewing of the film and only a few patrons remained in the cinema. Five photographs are used in the final credits and this time the photographs are of Indigenous people in situations much more redolent of violence or a post-violence moment.

The first photograph is of the Native Police. Then there is an image of Indigenous peoples arranged in lines-as on a church mission; another is of a huddled group of Indigenous women; this is followed by a photograph of Indigenous men in neck chains and a finally a staged studio photograph of a nonIndigenous man attacking an Indigenous man. The set of photographs used in the opening credits seemed to indicate an alternative vision to the story of violent relations between different groups on the frontier. For example, one photograph features three men standing side by side in a photography studio. Each has a long beard and is neatly dressed in quite similar jackets and neckwear (scarf, cravat, tie). The comparable clothing and demeanour creates a visual uniformity (equality) between the men, though two are Indigenous and one is non-Indigenous. The photographs in the closing credits comprise the more common images of violence and 
colonial coercion that have become familiar narratives of the frontier in the last thirty years in Australia.

In the interlude between the two photo montages (that is, in the bulk of the film), the narrative is of violence, but not violence solely directed at Indigenous people, but a general, chaotic, indiscriminate violence; "a verminous, barbarous melee in which the notion of a Western 'code' or value system is a bleak joke" (Langford, 33). Though Indigeneity and violence (not always coupled together) is the central motif of the two sets of credits, it is not the focus of the film. Rather the focus is on the tussle between good and bad (or shades of grey) in relation to English and Irish colonizers. Indigenous peoples play bit parts in this tale. The effect is to centralise the violent and murky process of British or non-Indigenous possession but not Indigenous dispossession (Morton-Robinson 24).

The differences between Irishness and Englishness and their place on the frontier, rather than Indigenous peoples, are central to the narrative. The plot is organised in terms of an ethnically heterogeneous scene. The brutal free for all of violence that is represented in The Proposition makes visible the intimacy of the frontier as well as the shifting allegiances between Indigenous peoples, the Scottish, the English, the Irish, the Welsh. However, in representing the complexity of this violent community there is not much space for the recognition of the logic of the colonizer/ and dispossessor in relation to colonized and dispossessed. And as Tanya Dalziell argues when these relations are addressed in the film they take place in the "civilized" space of the Stanley's garden (Dalziell 126).

\section{The Frontier, Civilization and Violence}

Violence is the central motif of the Western: "the Western is in large part about violence and the rituals, protocols and moral negotiation that surrounds violence" (Plantinga 65-83). As Richard Slotkin has argued, in the classic Western violence is required in order to eradicate evil and for the "regeneration" of the hero/community (Slotkin). As a revisionist or antiWestern, The Proposition muddies what Hillcoat calls the epic battle between "the law and the outlaw, the oppressor and the oppressed, man and nature" (cited in Cenere 40). The momentum for the film's narrative is provided by the murder of a non-Indigenous familyhusband, wife, child. The chief suspects are the Burns gang-in particular Arthur Burns, the eldest of three Irish brothers, a homicidal sociopath. The authorising of a morally questionable method for punishing Arthur Burns - the eponymous proposition - sets off a new cycle of violence in an already violent space, a violence that Collins likens to a Benjaminian sense of historical catastrophe (Collins 62).

The law is represented by Captain Stanley-the police officer in charge of the region and the man now hunting the killers. Stanley as a married man (the only one in the film) crosses constantly between the "feminine" home space occupied by his wife Martha and the "masculine" jail where he works. The Stanley's are the site of "civilization" in the text. Their house is a "little England" including roses, porcelain and silverware. It is future oriented; a place of potential, of hope (plants are growing, consumer goods are purchased, children feature in dreams). It has potential to be the (national) future (yet, as will be discussed later, it is in this space that the hyper-violent climax of the film takes place.) Captain Stanley fits the normative type expected of a hero in a Western: "both dominant and deferential, gentle and violent, [...] bridg[ing] [...] not simply the division between savagery and civilization, but the anxiously guarded (ambiguously experienced) frontier between the two worlds usually coded as masculine and feminine" (Michell 27). Stanley has just arrived in Banyon the type of "barely constituted township" so often found in the Western (Langford 33). He has an explicit agenda to bring "civilization" to the lawless space. For example, when he brings the first member of the Burns gang into town to be placed in jail, he says to the gathered townspeople, "I will civilize this land". Later to his wife Martha he says: "I had an idea about justice for the town for the country for you".

Yet the viewers' first substantial encounter with the Captain is when he is telling Charlie Burns that he, Captain Stanley, has "kept company with bad men all my life". It is at this point that Stanley makes the amoral proposition, what Carol Hart calls "his lawless contract" 
with Charlie Burns who is his prisoner (Hart). Stanley's claim to Charlie Burns that he has spent twenty-two years in Her Majesty's land forces and that this has constantly placed him in proximity to "bad men", suggests that this proximity to difference is required in the policing of the colonial space and the production of "civilization". Drawing on Sara Ahmed's ideas of strange bodies and intimacy, this closeness between police and "bad men"-convicts, criminals, Indigenous people-is what brings a white Australian nation into being. "Strange bodies" marked out the emerging Australian nation not by their distance from it but their proximity to it. They "allow[ed] the demarcation of spaces of belonging: by coming too close to home, they establish[ed] the very necessity of policing the borders of knowable and inhabitable terrains" (Ahmed 3). Indeed in one scene the Burns brothers put on police uniforms (that they have taken from the corpses of men they have murdered) to try and free their gaoled sibling. In order to pass without notice as the policemen as they enter the town, the gang drag an Indigenous man as a prisoner behind their horses. This barbaric act further enables them to be misrecognised as police.

The proposition suggested by Stanley is that if Charlie agrees to kill his monstrous eldest sibling, Arthur, who is still at large, he can save himself and his "simple" younger brother Mikey, who is also under arrest, from hanging. The film invites the viewer to sympathise with Captain Stanley in making the deal. However, we are also perceptually aligned with other views (Smith) - for example Martha Stanley, whose friend was one of the people murdered by the gang, and squatter Eden Fletcher who sees no justice in the deal. The scene of Mikey Burns being brutally flogged (a corporal punishment that leads to his death) in an act of vigilantism, watched by the passive and mute townsfolk, including Martha Stanley, reinforces the possibility of the "justice" of Stanley's solution. However, narratively it also means that the careful yet amoral negotiations Captain Stanley made to get one brother to assassinate another in the interests of the community is a waste of time. With Mikey's death the proposition is meaningless and the town is now hurtling towards the next brutality.
The film takes an ironic stand in relation to the notion of civilization and the West. Through the repeated and intensifying scenes of violence, it starkly shows up the emptiness of the claim that white-ness, European-ness or the West can be equated with morality or progress. This is represented in a series of scenes, of which the townspeople of Banyon watching as the youngest Burns brother is ferociously flogged is key. This long scene is inter-cut with images of Charlie Burns, who has recently been speared by an Indigenous man, watching his brother Arthur and trying to decide whether to kill him. A few minutes later, one of the members of the Burns gang jumps up when he hears gunshots. Arthur calms him by saying: “Troopers' rifles, 450 , shooting blacks, be calm Samuel, the shots are miles away". A long panning shot of a sunset is then replaced by another shot: this new scene is dark and quiet and the closer shot moves across dozens of bloodied Indigenous corpses. The next scene begins with a close up of a bloodied non-Indigenous hand holding a cigarette and then captures a group of Indigenous and non-Indigenous troopers drunkenly singing "Rule Britannia". In a stunning scene a little later, Two Bob, an Aboriginal member of the Burns gang, slits the throat of a police tracker. Two Bob says "here's your knife back you dog" as he walks past the dead body. The outcome of the violence that is generated in the narrative is not the clichéd "regeneration" of the Western but a vicious bloodletting, reflecting the layering of death and guilt on the colonial frontier.

Death and violence are the tropes of the frontier. The space where The Proposition was filmed-Winton Queensland-is marked by inter-racial violence as many outback spaces are. Jane Stadler draws attention to it as the site of a massacre at what is now called Skull Hole. She suggests the earlier described murkily presented massacre scene references this historical atrocity (71-2). However as Ross Gibson notes, though talking about another part of Queensland, the "traces" of the violence are often hard to locate. Thinking of the fictional Banyon: there is no newspaper in the town; no official records are kept; bodies are frequently being buried, some in simple graves with flimsy markers that will weather and disappear, others in unmarked sites. Traces of the violence disappear. 
The History Wars emerged in response to the emergence of colonial violence as a central issue in late twentieth-century discussions about race relations. The appearance of this narrative in everyday discourse was not a first. Accounts of this type of violence can be found in Indigenous narratives about colonisation, in the mapping of the colonial process (e.g. "Massacre Creek") and in earlier popular and scholarly accounts of the settlement process. However, the mid-twentiethcentury emergence of a dominant historical narrative that was "confident and authoritative $[\ldots]$ create $[\mathrm{d}]$ the conditions for the forgetting" of original violence (Davis 11). Though Richard Davis argues that this forgetting is "more apparent than real as the 'hidden histories' of violent encounter constantly haunt settlement" (11).

The controversy that circulates about massacre in contemporary Australian historiography attests to this disappearance of traces of violence: "Secrecy, ambiguity and inconclusiveness are part of what happened" (Gibson 69). Ross Gibson writes that the colonizers who arrived in this "funeral ground" after the initial brutality "tried to regard the place as new and unstained, as if there was nothing residual to see, touch, feel and believe" (83). In many ways The Proposition offers a postcolonial narrative that rakes up the bones hidden in this blank-ed space. The film, book-ended by the historical photographs, presents itself as a history of this disappeared violent history. In The Proposition the town's folk walk the streets, almost gliding; they stare at passers-by, mutely as if they are not quite anchored in this world. The town almost has the quality of a ghost town - the only buildings of substance being the jail and the Stanley's house. Dead bodies are strewn across the landscape in the many scenes of massacre. The space is not sacred but "defiled and profane" (Kollin 562). The Proposition seeks in some way to enunciate the violence of the frontier and to come to terms with the trauma of the space. The film can be classed as one of Adrian Martin's "haunted" films; a type of film that he notes makes it: "impossible for us to look at the land without sensing or reading traces of phantoms, crime, genocide, the dead [... ] the land seems to be weeping and disgorging its long buried voices and bones" (26).
Traditionally the dominant histories of Australian colonization have "shielded civilised people from the knowledge that murder and undeclared war were the reason they 'owned the land" (Gibson 73). The Proposition works against this. Yet, even in the reworked history produced by the film there is still an erasure of the centrality of Indigenous dispossession to the process of colonization (Dalziell). Davis suggests the "symbolic function" of Indigenous peoples in the ideology of the frontier is "to create the privileged and naturalised status of the settler" (Davis, 13). The Proposition explicitly represents the brutality and randomness of police violence directed towards Indigenous people. It also represents the reciprocal violence of Indigenous peoples to colonisers and their enemies. These mutual representations of violence, albeit negatively, suggest the "negotiable, liminal, contested and transformative exchanges" between Indigenous and non-Indigenous peoples on the frontier (Davis 13). What the film lacks is a mechanism for acknowledging the power differential between the different groups, in their violence. NonIndigenous violence needs to be recognised in terms of its genocidal intent and its refusal to recognise Indigenous sovereignty. That these intentions underpin violence on the frontier is underplayed or ignored.

\section{Family and Nation}

The Proposition, set as it is in the period leading up to federation in 1901, could easily have produced a nationalist narrative that (re)constructed the story of the emergence of the bush legend; or produced a narrative of a landscape that foretold the emergence of this future white national body. Rebekah Brammer notes the contrast in Ned Kelly (2003) and The Proposition in their representations of the coming nation (158). Ned Kelly is romantic; The Proposition is not. Though the latter does make it explicit how "strange" bodies are regulated and how they are eradicated when they "come too close to home", it produces no national body (Ahmed). Earlier I quoted Hillcoat deploring the failure to explore difficult issues in much Australian historical film. Given this distaste I would suggest it is not surprising the film refuses to name or mark out a good nation or a history 
that provides the genealogy for a good Australia. There is no (future) Australian in the film. For example, in the final section of the film, where the Burns gang brutalize the Stanleys in revenge for the death of the youngest brother, the violence is framed in terms of an AngloCeltic hatred. Captain Stanley is marked as English-his head wrapped by Arthur Burns in a Union flag. Burns is marked as Irish - in the brutal moment as he watches a member of his gang sexually assault Martha Stanley, he nostalgically remembers Ireland, through song.

This violence is only curtailed when Charlie Burns arrives and shoots Simon and Arthur. Rather than the conventional Western denouement where "the frontier moves, it passes, and what is left behind is no longer a frontier" (Rose 122), what happens instead is that savagery overtakes civilization, the wild overwhelms the domestic. It is not certain at this point that anything good will emerge from the frontier. The film does not produce a narrative of a coming Australia, or at least not a narrative of a potential Australia that is anything other than bleak.

The Proposition is not a film about a nation. The idea of community it works with is clan, or family, marked by ethnicity. The two key-though imperfect-families are the Stanleys and the Burns-an Irish family and an English family. The Burns family-made up of the three Irish brothers, a couple of other young Irish men, and two Indigenous people, Queenie (Leah Purcell) and Two Bob (Tommy Lewis) — are sociopathic misfits. ${ }^{4}$ The Stanleys are the alternative family. However, though they are nothing like the Burns, in this revisionist view of Australia, neither are they perfect. They are not represented unproblematically as the future of the nation. Scenes of Martha Stanley retelling her dreams of being handed a baby by the dead Eliza Hopkins and her wistful reading of catalogues filled with children's clothing suggest that the couple will not have children. The reproductive (national) family-the Hopkins with their child-have been murdered. At the film's end the Stanleys are left in a blood splattered room; he is beaten to a pulp, she has been raped, their ability to procreate in doubt.

The film mostly avoids the classic elegiac effect where Indigenous peoples are variously celebrated and mourned as they "vanish" from the frontier "poised in noble obsolescence against the ambivalent sunset/ sunrise culturescape of manifest destiny" (Langford 28). It is the three Irish brothers who enact the "disappearing tribe" role. There are various shots of Charlie and Arthur on outcrops. The Australian DVD release of the film features a lone figure of Charlie Burns silhouetted against a sunset. The final scene of the film enacts the "passing" of the brothers-Charlie is the sole survivor of the gang/family. The rest are dead or dispersed. Unlike the Burns and Stanleys, Indigenous peoples are not represented in terms of community of family. Rather the main characters-Queenie, Two Bob, Jacko and Tobey-appear as isolated individuals. Yet, even in this isolation, Indigenous peoples are actively negotiating their survival in the frontier space of The Proposition. Queenie and Two Bob as members of the Burns gang have found themselves a place in this family.

The Proposition attempts transformation from the unspeakable to the ordinary (Gibson 82). It seeks to move frontier violence from the margins to the centre. Implicit in Gibson's notion of the transformation of trauma is the suggestion that this transaction has a cost. In The Proposition it is the marginalised Irish family who seem to have to bear the cost of colonialism Charlie Burns must bury one brother and kill the other. The English couple, the Stanleys, are battered but alive. As the film moves towards its violent conclusion, the Indigenous peoples have actively absented themselves, moved themselves to the margins. Tobey, the servant in the Stanley household, leaves the house just before the violent "shoot out". He moves himself to a safe place-he is not to be part of the brutish and deadly violence that will take place in this site. Yet, in voluntarily walking out of the potential national space of the white household, he walks out of history and into the unknown (see also Dalziel's reading of this scene). In some ways Tobey voluntarily dispossesses himself.

\section{Conclusion}

The film, The Proposition, fiercely contests the dominant Australian narrative of unproblematic colonial and economic expansion. It explicitly links the colonial process with the suffering of Indigenous 
peoples, bringing into view the barbaric racism of various white individuals both towards one another and towards Indigenous peoples. Yet it is also a film about the cost of colonisation for "white" people. In the end the political critique provided in The Proposition of the white colonization of Australia and the destruction of Indigenous peoples and cultures collapses back into a story about white men struggling for redemption. The narrative becomes one about how good men (good white men), "stained" by contact with these "racial 'other[s]"' can achieve whiteness again (Meyer 180). In this text it is Irish-ness, an identity that has historically been made "black", that is the site of pain and loss. As noted earlier, the final film credits centralise Indigenous peoples and colonial violence with the use of historical images. These montages implicitly suggest that even though in the film's narrative they have been pushed to the margins, it was Indigenous peoples who continued to suffer the systemic violence of colonialism on the frontier. However, the final credits are a little viewed part of a contemporary film.

This film invites viewers to recognise the cost of colonialism-the blood that was spilt in forming a nation or settling the land. Hillcoat's claims of the varieties of violence considered-not just white on black and vice versa, but white on white, black on blacksuggests a recognition of the complexity of the frontier allegiances. In The Proposition, the blood that seeps into the "badlands" of the nation is white blood, non-white blood, Indigenous blood, and non-Indigenous blood. Yet the blood the viewer is perceptually asked to worry about is mostly white blood. In the film's final scenes in the Stanley's house-the site of civilisation, the tamed land-it is the blood of the Irish Arthur Burns that literally seeps into the garden bed to nourish the roses. The blood of the un-named Indigenous men who have died throughout the film does not mark this space of possibility. Indigenous blood is seen only in passing. This is not a film about dispossession. John Hillcoat said he always wanted to make a Western and in some ways he has made a classic Western-one where Indigenous peoples are the back-drop in front of which non-Indigenous peoples shoot it out to see who owns the land and what the shape of the nation will be. The final scene with the two Irish brothers, one dead, one alive, facing west; the film's final words a question about a bleak future is a powerful image of the ambivalence of the Australian past, present, future, but it is one that still sidelines Indigenous peoples.

\section{Notes}

1. What animated many of the films of the first decade of the twenty-first century were two different public debates that had been taking place in Australia in the late twentieth century. One was the debate that emerged from the Mabo and Wik native title decisions, Bringing them Home and the reconciliation decade. The High Court recognition of native title made Indigenous land claims more visible and gave them a legal resonance they had lacked to date. The second was the "history wars" - a debate about the writing of frontier or early colonial history -especially the issue of the veracity of accounts of non-Indigenous peoples' violence and the incidence of massacre. The history debates about violence reframed understandings of the ways the frontier experience and modes of land acquisition had occurred across the nineteenth and twentieth centuries. These debates unsettled historically stable beliefs about the peaceful transfer of land of many non-Indigenous peoples. A third strand that animated these discussions was the post 2001 federal governments stance on the arrival of unauthorised potential refugees. The policies of both the Howard and the Rudd/Gillard governments have highlighted the limits of imagining "others" as part of the nation.

2. See for example: Once Upon A Time in the West (Sergio Leone, 1969), Walker (Alex Cox, 1987), Unforgiven (Clint Eastwood, 1993), The Assassination of Jesse James by the Coward Robert Ford (Andrew Dominik, 2007), 3:10 To Yuma (James Mangold, 2007), True Grit (Ethan and Joel Coen, 2010) and on television HBO's production Deadwood (David Milch, 2004-6).

3. Tanya Dalziell discusses this in her article on the film "Gunpowder and Gardens: Reading Women in The Proposition, Studies in Australasian Cinema vol. 3, no. 1 2009, pp. 121-31.

4. In a scene late in the film Arthur Burns uses the word misanthrope. One of the gang asks what it means and is told it is someone who hates all humanity. The gang member asks if this is what they are and Arthur says no "we are a family".

\section{References}

Ahmed, Sara. Strange Encounters: Embodied Others in Postcoloniality. London: Routledge. 2000. Print. 
Australian Broadcasting Corporation 2005 'At the Movies', http://www.abc.net.au/atthemovies/txt/s1474241.htm, viewed, 1 November 2007. Online.

Brammer, Rebekah. "Ned Kelly vs The Proposition: Contrasting Images of Colonialism, Landscape and the Bushranger." Metro Magazine: Media \& Education Magazine 158 (2008): 132-5. Online.

Cawelti, John. The Six Gun Mystique. Bowling Green: Bowling Green University Popular Press, 1984. Print.

Cenere, Phillip. "The Good, the Bad and The Proposition." Metro Magazine: Media \& Education Magazine 148 (2005): 38- 41. Online.

Collins, Felicity and Therese Davis. Australian Cinema After Mabo. Cambridge: Cambridge University Press, 2004, Print.

Collins, Felicity. "Historical Fiction and the Allegorical Truth of Colonial Violence in The Proposition." Cultural Studies Review, 14.1 (2008): 55-59. Online.

Dalziell, Tanya. "Gunpowder and Gardens: Reading Women in The Proposition." Studies in Australasian Cinema 3.1 (2009): 121-131. Online.

Davis, Richard. "Introduction: Transforming the Frontier in Contemporary Australia”. Deborah Bird Rose and Richard Davis (eds). Dislocating the Frontier: Essaying the Mystique of the Outback. Canberra: ANU E Press, 2006. Online.

Diprose, Roslyn. "Where' your people from, girl?": Belonging to Race, Gender, and Place Beneath Clouds." differences 19.3 (2008): 28-58. Online.

Gibson, Ross. Seven Versions of an Australian Badland. St Lucia: University of Queensland Press, 2002. Print.

Hart, Carol. "Portraits of Settler History in The Proposition." Senses of Cinema 38, (2006) http://www. sensesofcinema.com/contents/06/38/propositions. html.

Heffernan, Jeanne. "Poised between Savagery and Civilization': Forging Political Communities in Ford's Westerns." Perspectives on Political Science. 28.3 (1999): 147-51. Online.

Keller, Alexandra. "Historical Discourse and American Identity in Westerns Since the Regan Administration." Film \& History: An Interdisciplinary Journal 33.1 (2003): 47-54. Online.

Kollin, Susan. "Genre and Geographies of Violence: Cormac McCarthy and the Contemporary Western." Contemporary Literature 42.3 (2001): 557-588. Online.

Krausz, Peter. "The making of an Australian western: John Hillcoat and The Proposition." Metro Magazine: Media \& Education Magazine 146-147 (2005): 16-20.
Langford, Barry. "Revisiting the 'Revisionist Western". Film and History, 33.2 (2003): 26-35. Online.

Limbrick, Peter. "The Australian Western, or A Settler Colonial Cinema par excellence." Cinema Journal 46.4 (2007): 68-95. Online.

McClintock, Anne. Imperial Leather: Race, Gender and Sexuality in the Colonial Contest. London: Routledge, 1995. Print.

McFarlane, Brian, "Outback and Brokeback." Meanjin 65. 1 (2006): 65-71. Online.

McIntyre, Stuart and Anna Clark. The History Wars. Melbourne: Melbourne University Press, 2004. Print.

Martin, Adrian. "On the Level: The Dark Side of Australian Cinema in Wolf Creek and The Proposition." Photofile 76, (2005): 24-27. Online.

Meyer, Susan. "Colonialism and the Figurative Strategy of Jane Eyre" in Jonathon Arac and Harriet Ritvo (eds). Macropolitics of Nineteenth Century Literature: Durham: Duke University Press, 1991. Print.

Mitchell, Lee Clark. Westerns: Making the Man in Fiction and Film. Chicago: University of Chicago Press, 1996. Print.

Moreton-Robinson, Aileen. The White Possessive: Property, Power and Indigenous Sovereignty. Minneapolis: University of Minnesota Press, 2015. Online

Plantinga, Carl. "Spectacles of Death: Clint Eastwood and Violence in Unforgiven." Cinema Journal 37.2 (1998): 65-83. Online.

Rose, Deborah Bird. "Australia Felix rules OK!". Gillian Cowlishaw and Barry Morris (eds). Race Matters: Indigenous Australians and 'Our' Society. Canberra, Aboriginal Studies Press. 1997.

Routt, William D. "More Australian than Aristotelian: the Australian Bushranger Film, 1904-1914." Senses of Cinema 18 (2001): np. Online

Smith, Paul. Engaging Characters: Fiction and Emotion in the Cinema. Oxford: Oxford University Press, 1995. Print.

Schafer, Roy. "Narration in the Psychoanalytic Dialogue." Critical Inquiry. Autumn, (1980): 29-53. Online.

Slotkin, Richard. Gunfighter Nation: The Myth of the Frontier in Twentieth-Century America. New York: Atheneum, 1992. Print.

Stadler, Jane. "The Proposition: The outback landscape and 'negative spaces' in Australia's colonial history.' Metro Magazine: Media \& Education Magazine 163 (2009): 63-73.

Starrs, Bruno. "The Tracker (Rolf de Heer 2002) and The Proposition (John Hillcoat 2005): Two Westerns 
That Weren't?" Metro Magazine: Media \& Education Magazine 153 (2007): 166-172.

Stoler, Ann Laura. Race and Education of Desire: Foucault's History of Sexuality and the Colonial Order of Things. Durham: Duke University Press, 1995. Print.

Weinberg, Scott. Review The Proposition, 2005, http:// www.efilmcritic.com. Online

\section{Filmography}

Beneath Clouds. Dir. Ivan Sen. Australian Film Finance Corporation and Autumn Films, 2002. DVD.

Black and White (2002) Dir. Craig Lahiff. Helen Leake and Nik Powell, 2002. DVD.

Ned Kelly. Dir. Gregor Jordan. Australian Film Commission and Australian Film Finance Corporation, 2003. DVD.

One Night the Moon. Dir. Rachel Perkins. ABC and Australian Film Commission, 2001. DVD.

Rabbit Proof Fence. Dir. Phillip Noyce. Rumbalara Films and Australian Film Commission, 2002. DVD.

The Proposition. Dir. John Hillcoat. UK Film Council and Surefire Film Productions, 2005. DVD.

The Chant of Jimmy Blacksmith. Dir. Fred Schepisi. The Film House and Victoria Film, 1978. DVD.

The Tracker. Dir. Rolf de Heer. Adelaide Festival of Arts and Australian Film Commission, 2002. DVD.

Wake in Fright. Dir. Ted Kotcheff. Group W and NLT Productions, 1971. DVD.

Recebido em: 29/02/2016

Aceito em: 03/05/2016 